\title{
Produksi Metabolit Sekunder Melalui Kultur Jaringan
}

\author{
Ellok Dwi Sulichantini \\ Laboratorium Kultur Jaringan, Fakultas Pertanian, Universitas Mulawarman. \\ Jl. Pasir Balengkong Kampus Gunung Kelua Samarinda, 75123. \\ Telp.081347524712. Email: ellokds@gmail.com
}

\begin{abstract}
ABSTRAK
Kultur jaringan adalah istilah umum yang digunakan untuk mendifinisikan suatu metode perbanyakan tanaman secara in vitro dengan menggunakan sel, jaringan, organ yang ditumbuhkan dalam media buatan yang kaya akan nutrisi dalam kondisi aseptik dalam wadah yang tembus cahaya. Melalui teknik kultur jaringan produksi metabolit sekunder juga dapat dilakukan. Kandungan metabolit sekunder dapat lebih besar apabila dihasilkan melalui teknik kultur kalus dan kultur suspensi sel daripada dari tumbuhan itu sendiri. Produksi metabolit sekunder dipengaruhi oleh eksplan, yaitu genetik dari eksplan, jenis eksplan seperti jaringan meristem, daun, kotiledon, hipokotil atau biji dan umur fisiologis dari eksplan. Eksplan terbaik adalah eksplan yang masih muda, yang berasal dari jaringan meristimatik. Pemilihan jenis dan konsentrasi zat pengatur tumbuh harus disesuaikan dengan tipe kultur dan spesies tanaman yang dijadikan sumber eksplan. Penambahan vitamin dapat mengurangi stres dan meningkatkan pertumbuhan suatu kultur. Jumlah sukrosa yang ditambahkan dalam media bervariasi antara 1-10\% tergantung jenis kultur dan spesies yang dikulturkan. Peningkatan senyawa metabolit sekunder dapat dilakukan dengan pemberian elicitor satu atau beberapa kali selama periode kultur. Penambahan elicitor dapat menghambat pertumbuhan kultur.
\end{abstract}

Kata kunci : kultur jaringan. metabolit sekunder, kultur kalus, kultur suspensi sel, zat pengatur tumbuh, sukrosa, elicitor.

\section{PENDAHULUAN}

Pemanfaatan tanaman untuk pengobatan sudah lama dilakukan. Bahkan sampai era modern saat ini pengobatan herbal banyak diminati masyarakat luas. Sebagian besar produk kimia yang dihasilkan oleh tanaman yang berupa metabolit sekunder mempunyai struktur yang kompleks sehingga sulit disintesis secara kimia. Metabolit sekunder selain dimanfaatkan sebagai obat, juga dimanfaatkan untuk bahan baku biopestisida, kosmetik, parfum dan perasa makanan. Pemanfaatan yang semakin luas akan meningkatkan keperluan akan bahan baku. Oleh karena itu program perbanyakan dan perbaikan sifat untuk meningkatkan kualitas dari bahan 
baku perlu terus dilakukan. Budidaya tanaman dapat dilakukan secara konvensional dan nonkonvensional atau melalui teknik kultur jaringan. Beberapa keuntungan pemakaian dari teknik kultur jaringan tanaman untuk produksi senyawa metabolit sekunder antara lain adalah: (1) dapat dilakukan sepanjang waktu, tidak tergantung faktor lingkungan seperti iklim, hama penyakit, hambatan-hambatan geografi dan musim, (2) sistem produksi nya dapat diatur, dimana produksi dapat dilakukan pada saat dibutuhkan dan dalam jumlah yang diinginkan, sehingga mendekati keadaan pasar yang sesungguhnya, (3) kualitas dan hasil produknya lebih konsisten dan (4) mengurangi penggunaan tanah untuk tujuan tersebut.

Penggunaan teknik kultur jaringan misalnya dengan cara kultur sel atau kultur suspensi sel untuk produksi metabolit sekunder memiliki keuntungan karena kandungan metabolit sekunder yang dihasilkan dapat diperoleh dalam jumlah yang lebih besar daripada dari tanaman itu sendiri. Produksi metabolit sekunder pada kultur dan tanaman dapat dilihat pada tabel 1.

Tabel 1. Produksi Metabolit Sekunder pada Kultur dan Tanaman

\begin{tabular}{|c|c|c|c|c|}
\hline \multirow{2}{*}{$\begin{array}{l}\text { Metabolit } \\
\text { Sekunder }\end{array}$} & \multirow[t]{2}{*}{ Jenis Tumbuhan } & \multicolumn{2}{|c|}{ Kandungan (\% BK) } & \multirow[t]{2}{*}{ Jenis kultur } \\
\hline & & Kultur & Tanaman & \\
\hline Shikonin & $\begin{array}{l}\text { Lithospermum } \\
\text { erythrorhizon }\end{array}$ & 20 & 1,5 & Suspensi sel \\
\hline Ginsenoside & Panax ginseng & 27 & 4,5 & Kalus \\
\hline Anthraquinon & Morinda citrifolia & 18 & 0,3 & Suspensi sel \\
\hline Ajmalisin & Catharantus roseus & 1,0 & 0,3 & Suspensi sel \\
\hline Nikotin & N. tabacum & 3,4 & 2,0 & Kalus \\
\hline
\end{tabular}

Sumber: Pandiangan dan Subarnas, 2011.

Perbanyakan melalui teknik kultur jaringan telah dilakukan untuk menghasilkan obat atau bahan obat yang berkualitas tinggi. Melalui teknik kultur jaringan juga dilakukan perbanyakan tanaman obat karena tingkat multiplikasi yang tinggi, sehingga dalam waktu singkat dapoat dihasilkan jumlah tanaman yang besar. Hal tersebut sangat bermanfaat untuk memperbanyak tanaman yang langka dan pohon yang berumur panjang. Regenerasi melalui teknik kultur jaringan telah terbukti dapat menghasilkan bahan kimia yang sama dengan tumbuhan induknya.

Produksi metabolit sekunder melalui kultur jaringan telah dilakukan pada beberapa tanaman diantaranya adalah vasine diisolasi dari Adhatoda vasica melalui kultur pucuk dengan menggunakan media MS+BAP+IAA (Shalaka and Sandhya, 2009); rosmarinic acid diisolasi dari Agastache rugosa melalui kultur akar berambut dalam media MW+2.4-D+Kinetin (Lee, et al., 2007); Azadirachtin diisolasi dari Azadirachta indica melalui kultur suspensi sel dalam media MS+2.4D; MS+2.4-D+Cyanobacterial elicitor (Poornasri et al., 2008; Sujanya et al., 2008); Flavones diisolasi dari Camellia sinensis dari kultur kalus (Nikolaeva et al., 2009) dan theamine diisolasi dari Camellia sinensis dari kultur suspensi sel dalam media MS+IBA+Kinetin (Orihara and Furuya, 1990). 
Pengembangan pada tahap komersil dengan menggunakan bioreactor untuk mmproduksi metabolit sekunder dalam jumlah besar. Sebagai contoh produksi saponin dengan bioreactor pada kultur akar ginseng dapat diperoleh $500 \mathrm{mg} / \mathrm{l} / \mathrm{hari}$ (Park, et al., 1992) dan produksi alkaloid ginsenosid dari kultur akar Panax ginseng dengan biorekaktor sebesar 1-10 ton (Hahn, et al., 2003). Teknik kultur jaringan dalam bioreactor ini jauh lebih efisien jika dibandingkan dengan cara konvensional (Radji, 2005).

\section{Faktor-Faktor Yang Mempengaruhi Produksi Senyawa Metabolit Sekunder}

\section{Eksplan.}

Keberhasilan teknik kultur jaringan juga sangat ditentukan oleh eksplan yang digunakan. Meskipun menurut teori totipotensi semua sel mempunyai kemampuan untuk beregenerasi menjadi individu baru namun kemampuan regenerasi tersebut sangat bervariasi tergantung pada genotipe, umur dan ukuran eksplan yang digunakan.

Berdasarkan teori totipotensi biokimia sel maka sel tertentu dari tanaman mempunyai potensi genetik yang diturunkan untuk menghasilkan senyawa dalam kultur in vitro seperti dalam kultur in vivo. Berdasarkan teori ini maka tanaman yang mempunyai kandungan senyawa kimia tertentu dalam jumlah besar juga akan mampu menghasilkan senyawa yang sama dalam jumlah besar apabila tanaman tersebut dikulturkan dalam kondisi in vitro. Sehingga informasi mengenai bagian tanaman yang mempunyai kandungan senyawa yang diinginkan perlu diketahui sebelum melakukan kegiatan kultur jaringan untuk mendapatkan senyawa metabolit sekunder. Bagian yang mengandung senyawa yang diinginkan dalam konsentrasi tinggi selanjutnya dapat digunakan sebagai sumber eksplan untuk produksi metabolite sekunder.

Pemilihan eksplan selanjutnya juga dipilih berdasarkan umur fisiologis dari sumber eksplan yang digunakan. Menurut Sulichantini (1998), semakin muda sumber eksplan yang digunakan akan semakin tinggi tingkat regenerasi yang dihasilkan. Sehingga tingkat keberhasilan kultur juga akan semakin besar. Untuk mendapatkan tanaman umur fisiologis yang muda dari tanaman yang sudah tua maka dapat dilakukan berbagai kegiatan rejuvenasi antara lain dengan grafting.

Ukuran eksplan juga perlu dipertimbangkan. Semakin kecil eksplan maka tingkat kontaminasi yang terjadi semakin rendah namun tingkat kematian eksplan akan semakin tingg. Sedangkan bila ukuran eksplan yang digunakan besar maka teknik isolasi eksplan lebih muda namun tingkat kontaminasi juga besar. Oleh karena itu perlu dilakukan percobaan untuk menentukan ukuran eksplan yang tepat sesuai dengan jenis tanaman, tipe kultur dan umur eksplan yang digunakan.

\section{Genetik.}

Faktor genetik merupakan salah satu penentu tingkat produksi senyawa metabolit sekunder yang dihasilkan. Tanaman yang berasal dari galur yang berbeda dari varietas yang sama sangat mungkin akan menghasilkan jumlah metabolit sekunder yang berbeda. Menurut Kinersley dan Dougall (1981) pada kultur kalus 
Nicotiana tabacum. Nikotin yang dihasilkan oleh kalus sangat tergantung pada genotipe dari tanaman induk sumber eksplan yang digunakan untuk menginisiasi kalus tersebut.

Pada tanaman tapak dara (Catharanthus roseus) kandungan vincristin dan vinblastin pada tanaman berbunga putih lebih tinggi daripada tanaman yang berbunga merah. Oleh karena itu yang umum digunakan untuk menghasilkan senyawa anti kanker adalah tapak dara yang berbunga putih (Pandiangan dan Subarnas, 2011).

Faktor genetik juga mempengaruhi produksi antocianin dari Polygonum tinchtorium Ait dari 6 kultivar yang digunakan sebagai sumber eksplan pada kultur kalus ternyata hanya 3 kultivar yang mampu menghasilkan antosianin. Empat kultivar dari 6 kultivar yang dicoba berbunga merah sedangkan 2 kultivar lainnya berbunga putih tetapi dalam kultur in vitro ternyata yang menghasikan antosianin hanya 3 kultivar. Ternyata antocianin tidak dihasilkan oleh organ bunga tetapi dihasilkan oleh organ batang (Ernawati, dkk., 1991). Oleh karena itu proses seleksi untuk menemukan galur yang mempunyai kandungan metabolit sekunder yang tinggi perlu terus dilakukan.

Tahap perkembangan organ juga memiliki kandungan metabolit sekunder yang berbeda. Hal tersebut dikarenakan perbedaan tingkat diferensiasi sel menentukan tingkat sintesis senyawa tersebut. Jenis tanaman yang berbeda juga bisa mempunyai pola sintesis yang berbeda. Misalnya pada produksi antocianin, pada wortel antocianin hanya ditemukan pada umbi sedangkan pada tanaman lain dapat ditemukan pada bunga, buah atau daun.

\section{Jenis Kultur.}

Jenis kultur yang digunakan maupun jenis eksplan yang digunakan juga dapat mempengaruhi produksi metabolit sekunder. Produksi metabolite sekunder tertentu pada tanaman tertentu dapat diperoleh dari kultur kalus atau kultur suspensi sel namun pada tanaman yang berbeda atau senyawa yang berbeda hanya dapat produksi dengan teknik kultur organ. Pada tanaman ginseng (Panaz ginseng), saponin dan metabolit lainnya banyak diproduksi di bagian akar oleh karena itu jenis kultur yang harus dilakukan untuk memproduksi metabolit sekunder adalah kultur akar secara in vitro. Tanaman herbal, Hipericum perforatum yang menghasilkan senyawa anti-depressant hypericins dan hyperforins pada daun, senyawa tersebut tidak dapat dihasilkan dari sel-sel yang belum berdiferensiasi (Smith et al., 2002).

Pada tanaman tapak dara, kandungan vincristin dan vinblastin yang merupakan obat anti kanker leukemia pada daun yang dihasilkan melalui teknik kultur jaringan lebih tinggi daripada kalus. Oleh karena itu untuk menghasilkan vincristin dan vinblastin sebaiknya diupayakan agar morfogenesis eksplan yang digunakan dapat membentuk daun (Pandiangan dan Surbanas, 2011).

Pada kultur Poligonum tinchtorium Ait, senyawa anti jamur yang dihasilkan pada kultur akar berambut lebih besar daripada kalus, sebaliknya dalam kultur yang sama senyawa antosianin yang dihasilkan pada kalus lebih besar daripada kultur akar berambut (Ernawati, 1990). Pada tanaman ginseng (Panax ginseng), saponin dan metabolit lainnya banyak diproduksi di bagian akar oleh karena itu jenis kultur 
yang harus dilakukan untuk memproduksi metabolit sekunder adalah kultur akar secara in vitro.

\section{Komposisi Media Kultur.}

Komponen penyusun media kultur jaringan antara lain adalah unsur makro, unsur mikro, sumber karbohidrat, asam amino, vitamin, arang akif, persenyawaan organik kompleks dan zat pengatur tumbuh. Sumber karbon yang dapat dipergunakan antara lain adalah glukosa, sukrosa, fruktosa, galaktosa dan manosa. Pemberian sukrosa dalam media dengan konsentrasi tinggi menyebabkan penurunan pertumbuhan dibandingkan konsentrasi yang lebih rendah pada kultur Nicotiana tabacum (Yasuda et al., 1972) dan Nicotiana rustica (Hunt and Loomis, 1976). Konsentrasi sukrosa dalam media kultur untuk produksi metabolit sekunder pada beberapa spesies tanaman dapat dilihat pada Tabel 2.

Tabel 2. Penggunaan Sukrosa dalam Menghasilkan Produk Metabolit Sekunder

\begin{tabular}{|c|c|c|c|}
\hline Species & Produk & $\begin{array}{c}\text { Konsentrasi } \\
\text { Sukrosa \% (b/v) }\end{array}$ & Daftar Pustaka \\
\hline Populus & antosianin & $1-5$ & $\begin{array}{l}\text { Matsumoto et al, } \\
1973\end{array}$ \\
\hline $\begin{array}{l}\text { Acer } \\
\text { psedoplatanus }\end{array}$ & lignin & $2-15$ & Carcellar et al, 1971 \\
\hline Morinda citrifolia & Antraquinone & 2 & Zenk et al, 1975 \\
\hline Nicotiana tabacum & Ubiquinone & $2-5$ & Ikeda, et al 1976 \\
\hline Costis japonica & barberine & $3-10$ & $\begin{array}{l}\text { Sato dan Yamada, } \\
1984\end{array}$ \\
\hline Digitalis purpurea & digitoxin & $3-10$ & Hagimori et al, 1982 \\
\hline Vitis & antosianin & $1.5-10$ & $\begin{array}{l}\text { Yamakawa et al, } \\
1983\end{array}$ \\
\hline Rosa sp. & polyphenol & $2-4$ & Davies, 1972 \\
\hline
\end{tabular}

Vitamin yang ditambahkan pada media kultur jaringan adalah thiamine, nicotinic acid, pyridoxine dan asam pantotenat. Keuntungan pemberian vitamin adalah dapat mengurangi stres pada eksplan, memperbaiki pertumbuhan, mengurangi pertumbuhan agregat yang abnormal pada kultur suspensi sel (Matsumoto, et al., 1976) dan mempercepat pertumbuhan kultur suspensi tembakau (Noguchi et al., 1977).

Zat pengatur tumbuh yang umum digunakan adalah auksin dan sitokinin. Golongan auksin yang sering digunakan adalah IAA, 2.4-D, IBA dan NAA. Sitokinin yang sering digunakan adalah BAP, TDZ, BA dan Kinetin. Peran auksin adalah dalam pembelahan sel, induksi kalus, induksi embriogenesis dan induksi akar. Sedangkan sitokinin berperan aktif untuk induksi tunas, multiplikasi tunas aksilar, menghambat pembesaran sel, menyediakan kondisi yang seimbang antara pembagian sel dan pembesaran sel serta sintesis protein. Pertumbuhan kultur selain dipengaruhi oleh konsentrasi zat pengatur tumbuh yang digunakan juga dipengaruhi 
oleh jenis zat pengatur tumbuh. Pada kultur Morinda citrifolia, penggunaan 2.4-D dapat meningkatkan produksi anthraquinone sebesar 30 kali dibandingkan dengan penggunaan NAA (Zenk, et al., 1975). Hasil yang berlawanan terjadi pada kultur suspense sel Vitis ternyata pemberian 2.4-D dapat menghambat sintesis anthosianin (Yamakawa, et al., 1983).

Produksi metabolit sekunder oleh tanaman merupakan respon pertahanan diri dari serangan pathogen. Produksi metabolit sekunder secara in vitro pada kultur kalus, kultur suspensi sel dan kultur akar berambut seringkali dapat ditingkatkan dengan pemberian elicitor. Pemberian elicitor dapat dilakukan lebih satu kali tergantung pada jenis kultur dan jenis tanaman yang digunakan. Waktu yang diperlukan oleh sel untuk menghasilkan produk dalam jumlah maksimal setelah pemberian elicitor juga berbeda-beda tergantung pada jenis kulturnya. Jeong dan Park (2007), melakukan percobaan pemberian elicitor abiotik untuk meningkatkan pertumbuhan dan biosintesis saponin pada kultur akar berambut Panax ginseng. Secara umum perlakuan pemberian elicitor menghambat pertumbuhan dari kultur akar berambut namun dapat meningkatkan biosintesis saponin ginseng. Tannic acid sangat menghambat pertumbuhan kultur akar berambut selama periode pertumbuhan. Penambahan $0,5 \mathrm{mM}$ selenium sebagai elicitor pada kultur umur 21 hari dapat meningkatkan saponin sebanyak 1.31 dan 1.33 kali dari kontrol. Menurut Jin, et al (1999), chitosan merupakan elicitor polisakarida biotic yang dapat meningkatkan produksi anthraquinone pada kultur sel Rubia akane.

\section{Kesimpulan}

Pemanfaatan bioteknologi dalam hal ini kultur jaringan memberikan keuntungan karena dapat digunakan untuk memperbanyak tanaman-tanaman langka dan berumur panjang yang digunakan sebagai penghasil senyawa metabolit sekunder. Keuntungan penggunaan teknik kultur jaringan adalah dapat dilakukan sepanjang waktu, tidak tergantung pada iklim dan musim; dapat diproduksi secara massal sesuai dengan jumlah yang diinginkan, mengurangi pemakaian lahan, dapat menghasilkan kualitas dan jumlah yang diinginkan. Peningkatkan pengetahuan tentang metode pelaksanaan dan faktor-faktor yang mempengaruhi keberhasilan kultur jaringan perlu terus dilakukan untuk meningkatkan efisiensi produksi. Kultur jaringan merupakan metode yang potensial digunakan untuk memproduksi senyawa metabolit sekunder.

\section{Daftar Pustaka}

[1] Carcellar, M., M.R. Davey, M.W. Fowler and H.E. Street. 1971. The influence of sucrose, 2.4-D and kinetin on the growth fine structure and lignin content of cultured sycamore cell. Protoplasma 73: 367

[2] Davies, M.T. 1972. Properties of invertases of culture sycamore cells and changes on their activity during culture growth. Pysiol Plant 26: 346

[3] Ernawati, A. 1992. Produksi senyawa-senyawa metabolit sekunder dengan kultur jaringan tanaman. Dalam Wattimena, G.A. (Ed.). Bioteknologi tanaman. 
Pp: 169-219. Departemen Pendidikan dan Kebudayaan. Direktorat Jenderal Pendidikan Tinggi. Pusat Antar Universitas Bioteknologi. Institut Pertanian Bogor, Bogor.

[4] Ernawati, A., S. Mayama and M. Kyo. 1991. Selection of anthocyanin and antifungal compounds of Polygonum tinchtorium Ait. Bulletin Agron. XX (1): 1 .

[5] Hahn, E.J., Y.S. Kim, K.W. Yu, C.S. Jeong and K.Y. Paek. 2003. Adventitious root cultures of Panax ginseng and ginsedoside production throught large scale bioreactor system. J. Plant Biotechnol. 5: 1-6.

[6] Hagimori, M., T. Matsumoto, Y. Obi. 1982. Studies on production of digitalis cardenolides by plant tissue culture III. Effects of nutrients on digotoxin formation by shoot-forming culture of Digitalis purpurea L. grown in liquid media. Plant Cell Physiol 23: 1025.

[7] Ikeda, T., T. Matsumoto, M. Noguchi. 1976. Effects of nutritional factors on the formation of ubiquinone by tobacco plant cells in suspension culture. Agric. Biol. Chem 40: 1765.

[8] Jeong, G.A. and D,H. Park. 2007. Enhanced secondary metabolite biosynthesis by elicitation in transformed plant root system. Appl. Biochem. Biotechnol. 130: 436-446.

[9] Jin, J.H., J.H. Shin, J.H. Kim, I.S. Chung and H.J. Lee. 1999. Effect of chitosan elicitation and media components on the production of anthraquinone colorants in madder (Rubia akane Nakai) cell culture. Biotechnol. Bioprocess. Eng. 4: 300-304.

[10] Kinnersley, A.M. and D.K. Dogall. 1981. Corelation between nicotine content of tobacco plant callus cultures In W. Alton Jones Cell Science Centre Annual Report pp 7-8. Lake Placid: W. Alton Jones Cell Science Centre.

[11] Lee, S.Y., H. Xu, Y.K. Kim, S.U. Park. 2007. Rosmarinic acid production in hairy root cultures of Agastache rugosa Kuntze. World J. Microbiol. Biotechnol. 20: 969-972.

[12] Matsumoto, T., K. Okunishi and M. Noguchi. 1976. Defined medium for crown gall cells of tobacco in suspension culture. Agric. Biol. Chem.. 40: 1335.

[13] Nikolaeva, T.N., N.V. zagoskina, M.N. zaprometov. 2009. Production of phenolic compounds in callus cultures of tea plant under the effect of 2.4-D and NAA. Russ. J. Pl. Physiol. 56: 45-49.

[14] Noguchi, M., T. Matsumoto, Y. Hirata, K. Yamamoto, A. Katsuyama, A. Kato, S. Azechi and K. Kato. 1977. Improvement of growth rates of plant cell cultures. In Plant tissue culture and its bio-technological application. Barz, W., E. Reinhard., M.H. Zenk (eds.), Springer-Verlag, Berlin.

[15] Orihara, Y. and T. Furuya. 1990. Production of theanine and other y-glutamil derivatives by Camellia sinensis cultured cells. Plant Cell Rep. 9: 65-68. 
[16] Park, J.M. and S.Y. Yoon. 1992. Production of sunguinarine by suspension culture of Papaver somniferum in bioreactors. J. Ferm Bioeng. 74: 292-296.

[17] Pandiangan, D. dan A. Subarnas, 2011. Produksi katarantin melalui kultur jaringan. Lubuk Agung, Bandung.

[18] Poornasri, D.B., A. Vimala, I. Sai and S. Candra. 2008. Effect of cyanobacterial elicitor on neem cell suspension cultures. Ind. J. Sci. Technol. $1: 1-5$.

[19] Radji, M. 2005. Peranan bioteknologi dan mikroba endofit dalam pengembangan obat herbal. Majalah Ilmu Kefarmasian. II (3): 113-126.

[20] Sato, F. dan Y. Yamada. 1984. Hight berberine producing cultures of Coptis japonica cells. Phytochemistry 23: 281.

[21] Shakala, D.K. and P. Sandhya. 2009. Micropropagation and organogenesis in Adhatoda vasica for the estimation of vasine. Pharmacognosy Magacine 5: 539-363.

[22] Sujanya, S., D.B. Poornasri, I. Sai. 2008. In vitro production of azadirachtin from cell suspension cultures of Azadirachta indica. J. Biosci. 33: 113-120.

[23] Sulichantini, E.D. 1998. Induksi embrio somatik dari beberapa tipe eksplan pada beberapa kultivar kacang tanah (Arachis hypogaea L.). Thesis Program Pasca Sarjana. Institut Pertanian Bogor, Bogor.

[24] Yamakawa, T., S. Kato, K. Ishida, T. Kodama and Y. Minoda. 1983. Production of anthocyanin by Vitis cells in suspension culture. Agric. Biol. Chem., 47: (10) 2185.

[25] Zenk, M.H., H. El-Shagi, H. Arens, J. Stockigt, E.W. Weiler and B. Deus. 1977. Formation of the indole alkaloid serpentine and ajmalicine in cell suspension cultures on Chatharanthus roseus. In Plant tissue culture and its biotechnological application. Barz, W., E. Reinhard., M.H. Zenk (eds.), SpringerVerlag, Berlin, 27 